\title{
DISTRIBUTION AND ABUNDANCE OF CRYPTOFAUNA FROM LIZARD ISLAND, GREAT BARRIER REEF
}

\author{
by \\ Patricia A. Hutchings ${ }^{1)}$ and Penny D. WeAte ${ }^{1)}$
}

\begin{abstract}
A series of replicate samples of dead coral reef habitats was collected across Yonge Reef on the outer and inner reef (back reef) and on fringing reefs around Lizard Island. Five categories of habitats were selected, branching, thin plates, high percentage of live coral, solid reef, rock with either a small surface area or a large surface area, and easily broken up. The surface area, volume, percentage cover of epifauna and flora, and biomass of cryptofauna were determined for each habitat. An estimate of the percentage of cavity space (i.e. available living space for cryptofauna) occurring in each habitat was made.

The cryptofauna is dominated by polychaetes, molluscs, and sipunculans. Habitats on inner Yonge have a larger biomass of cryptofauna than similar habitats found on outer Yonge or on fringing reefs around Lizard Island. Differences in physical attributes of the habitat together with exposure and surrounding species of coral and sponges may be responsible for these differences.
\end{abstract}

\section{INTRODUCTION}

Cryptofauna refers to animals that live in crevices or burrows inside live or dead coral. They can be divided into two categories, boring and 'opportunistic' species. The boring species such as sipunculans (WILLIAMS \& MARGOLIS 1974) bivalves (ARNAUD \& THOMASSIN 1976, GOREAU et al 1972, and SOLIMAN 1969) sponges (RUTZLER 1974, RUTZLER \& RIEGER 1973, THOMAS 1972) and certain species of polychaetes bore into the coral either mechanically (RICE 1969) or chemically. Polydorid polychaetes have been shown to chemically bore into shells, similar mechanisms may operate when polychaetes bore into corals (HAIGLER 1969, ZOTTOLI \& CARRIKER 1974). The 'opportunistic' species cannot bore and they utilise existing holes or crevices including some cheated by the borers. 'Opportunistic' species which normally constitute the major component of cryptofauna consist of crustaceans, echinoderms, gastropods (RICHARDS 1973) and polychaetes.

Qualitative work in the 1960's and 1970's by EBBS (1966), GRASSLE (1973) and REISH (1968), has shown that coral reef cryptofauna is abundant and diverse. Recently, workers have begun to study cryptofauna quantitatively. MCCLOSKEY (1970) obtained quantitative data for the cryptofauna occurring in a particular species of coral

I) Australian Museum, Sydney, New South Wales, Australia. 


\section{PATRICIA A. HUTCHINGS \& PENNY D. WEATE}

and KOHN \& LLOYD (1973) obtained similar data for truncated limestone reefs habitats. BRANDER et al. (1971) and PEYROTCLAUSADE (1974) determined the cryptofaunal biomass of particular habitats such as channel, subtidal coral platform and intertidal 'cobble' ridge or from various reef zones. BRANDER et al found that within a particular habitat a tremendous variety of substrates occurred e.g. sand, coral rubble, reef rock, live coral etc. These substrates were sampled in varying proportions each time, making comparisons of replicate samples almost impossible. They did however establish that certain substrates supported more cryptofauna than others and that most species avoided live coral. They also found that habitats with a large surface area tended to support a greater number of cryptofaunal animals than habitats with a small surface area. Later, HUTCHINGS (1974) attempted to identify some of the physical factors influencing the distribution and abundance of cryptofauna by looking at specific habitats within a single lagoon. The results showed that porous habitats with a large surface area and with a high cover of epifauna or flora supported the greatest biomass of invertebrates. This work which was carried out at One Tree Island on the southern part of the Great Barrier Reef is now being continued at Lizard Island (Lat $14^{\circ} 40^{\prime}$ S., Long $145^{\circ} 27^{\prime} \mathrm{E}$.). At Lizard Island the physical attributes of the habitats are being measured rather than assessed. Also similar habitats are being sampled in various localities and depths e.g. exposed and protected fringing reefs around Lizard Island and the outer slope and inner reef (back reef) of Yonge Reef on the outer barrier. In this paper we discuss the preliminary results obtained from habitats on outer and inner Yonge Reef and on exposed fringing reefs around Lizard Island.

\section{SAMPLING AREA}

Lizard Island is one of the high granite islands on the Great Barrier Reef. It lies $28 \mathrm{~km}$ off the Queensland coast at Cape Flattery. The outer barrier lies 20-25 km to the east of Lizard Island and forms an arc in a NW/SE direction. It consists of a series of reefs, Day, Carter, Yonge and Ribbon with narrow navigable passages separating adjacent reefs. Yonge Reef (Lat. $14^{\circ} 36^{\prime} \mathrm{S}$, Long $145^{\circ} 33^{\prime} \mathrm{E}$ ) is exposed to the SE trade winds which blow for about nine months of the year from February to November making sampling during this period very difficult. The reef has a narrow crest which is exposed only once or twice each year during exceptionally low tides. The reef slope drops rapidly to $40 \mathrm{~m}$ with good coral cover to $30 \mathrm{~m}$, below which there is a zone of loose coral rubble. Below $40 \mathrm{~m}$, the gradient is less severe and gradually becomes part of the ocean floor. The inner reef of Yonge is protected from trade winds and is 2-7 m deep with large masses of staghorn and isolated large bommies 


\section{DISTRIBUTION AND ABUNDANCE OF CRYPTOFAUNA}

with good coral cover, separated by sandy areas. The coral communities in this region are being described by PICHON (pers. comm). The fringing reefs on the NE side of Lizard Island located off rocky headlands, lie just below the surface to a depth of $20 \mathrm{~m}$. These reefs are also subjected to the SE trade winds.

\section{MATERIAL AND METHODS}

A twenty metre wide area was demarcated across the inner reef, reef crest and reef slope of Yonge and all the outer barrier habitats were selected within this area. The location of these sampling sites and those on the exposed fringing reefs around Lizard Island are shown in Figure 1. Five different categories of habitat were selected:
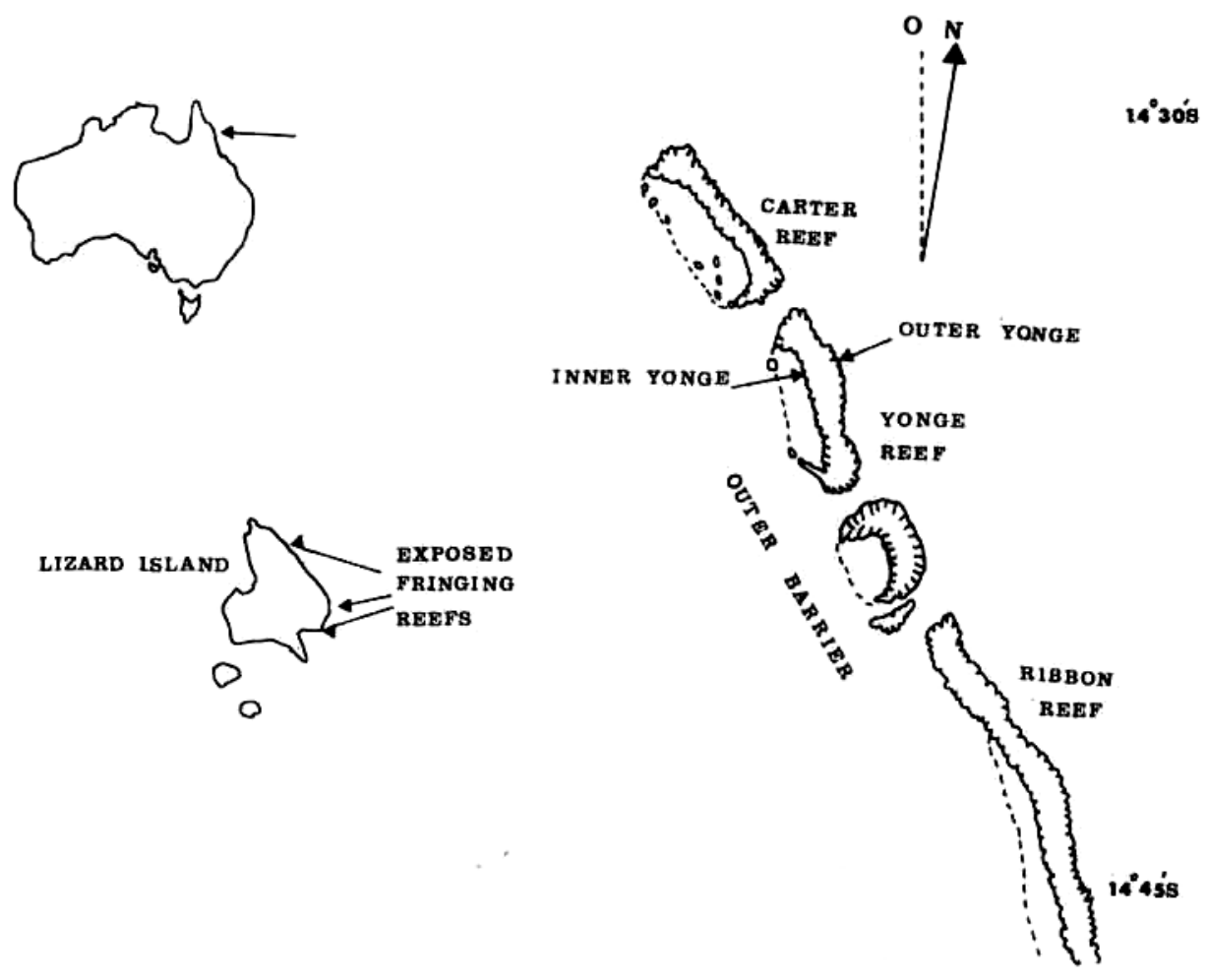

Figure 1. Lizard Island and the outer barrier showing location of sampling areas. 


\section{Patricia A. Hutchings \& PenNy D. We Ate}

(1) Solid reef habitats, composed of dead reef rock with a small surface area (Plate la \& b).

(2) Solid reef habitats composed of dead reef rock with a large surface area, covered with large amounts of epifauna and flora and easily broken up (Plate 1c \& d).

(3) Solid reef habitats with a high proportion of live coral (Plate le, f).
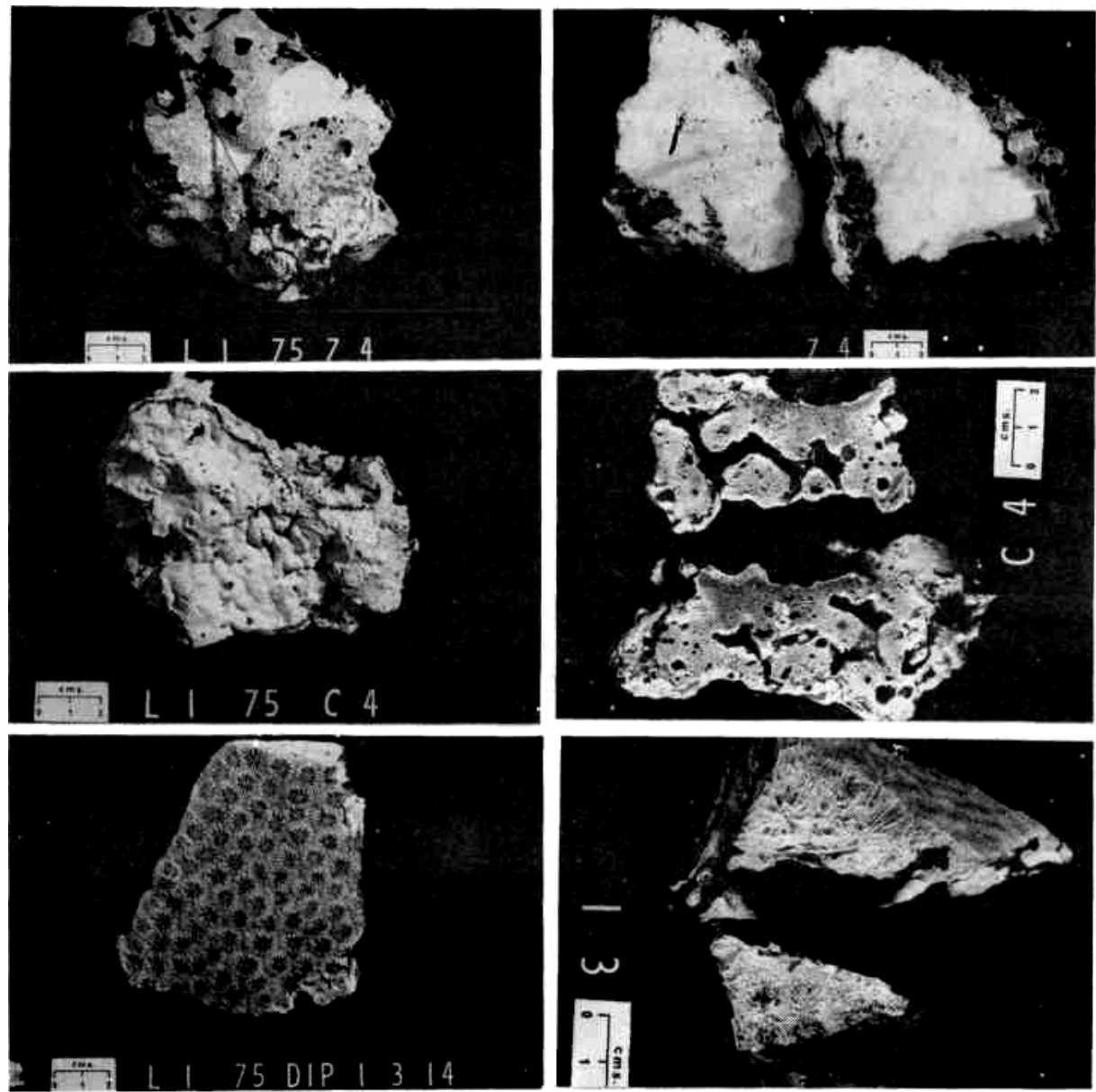

Plate la Dried solid reef habitat with small surface area, 1b T.S. solid reef habitat with small surface area.

1c Dried solid reef habitat with large surface area and easily broken up. $1 d$ T.S. solid reef habitat with large surface area and easily broken up. 1e Dried solid reef habitat with high proportion of live coral. 1f T.S. solid reef habitat with high proportion of live coral. 
DISTRIBUTION AND ABUNDANCE OF CRYPTOFAUNA
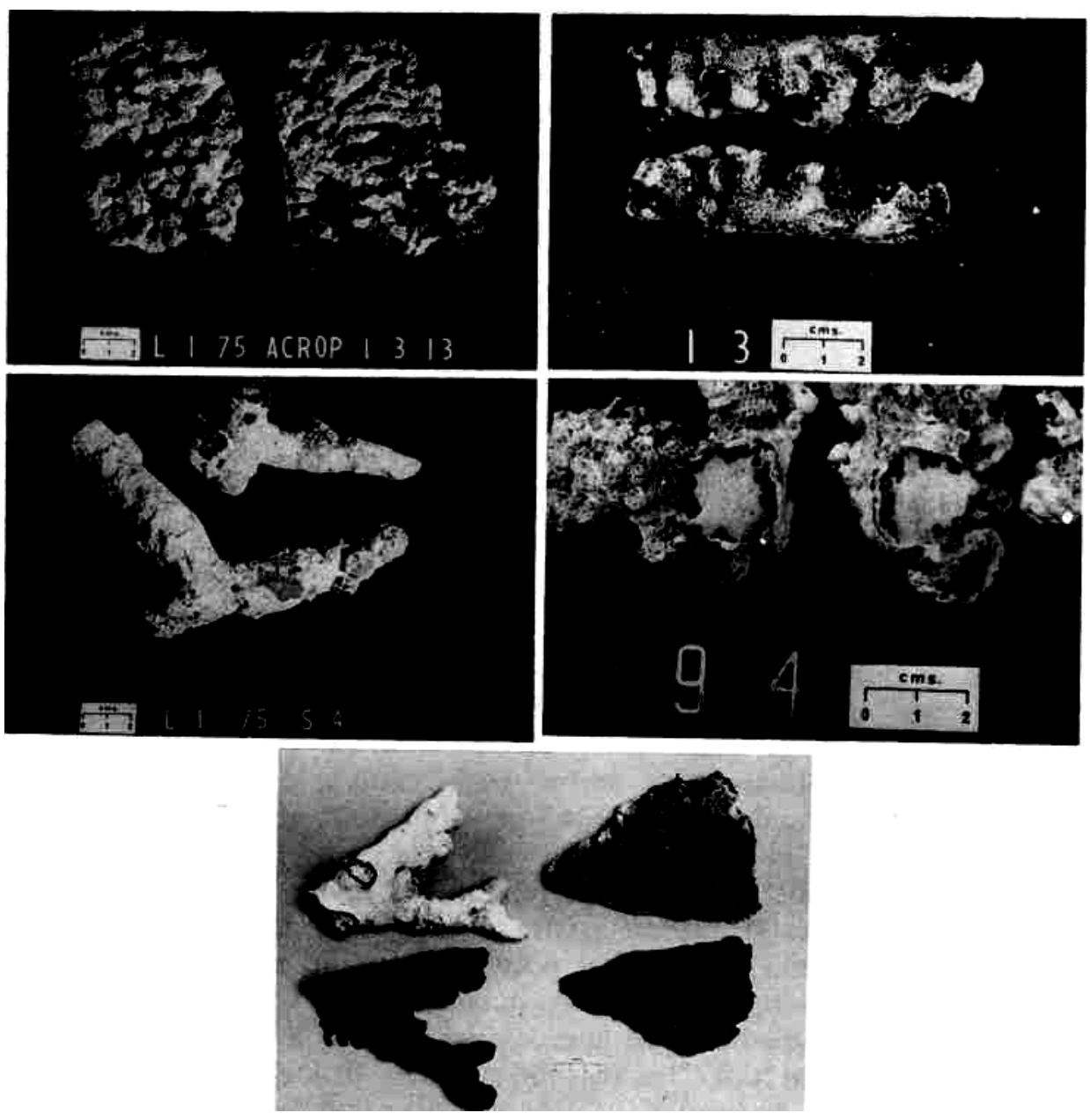

Plate 2a Dried thin plates dead coral.

2b T.S. thin plates dead coral.

2c Dried dead branching coral.

2d T.S. dead branching coral.

2e Latex moulds for measuring surface area of habitats.

(4) Thin plates of dead coral (Plate 2a, b).

(5) Dead branching coral (Plate 2c, d). 


\section{PATRICIA A. HUTCHINGS \& PENNY D. WEATE}

All samples were collected during January 1975. The habitats were visually classified underwater into the five categories, photographed, and the depth recorded. Samples $(0.6-\mathrm{l} \mathrm{kg})$ were broken off with a hammer and chisel, put into individual polythene bags and sealed. Four samples were taken of each habitat and the number of replicate habitats sampled in each category was as follows:

$\begin{array}{lccc} & \begin{array}{c}\text { Yonge Reef } \\ \text { Inner Reef Outer Reef }\end{array} & \begin{array}{c}\text { Lizard Island } \\ \text { Exposed Fringing Reef }\end{array} \\ \begin{array}{l}\text { Solid, reef habitats, low SA } \\ \text { Solid, reef habitat, large SA }\end{array} & 2 & 4 & 2 \\ \text { easily broken up } & 4 & 5 & 6 \\ \text { Habitats with live coral } & 1 & 1 & 3 \\ \text { Thin plates dead coral } & - & 1 & 1 \\ \text { Dead branching coral } & 4 & - & 1\end{array}$

The samples were wet weighed on return to the laboratory and the epifauna or flora assessed on a scale of abundance. Three samples of each habitat were broken into small pieces and fixed in 7\% neutralised formalin. The pieces were then further broken up and the animals extracted. The animals were sorted to phylum and each phylum wet weighed. The remaining sample of the four collected was put into bleach for 24 hours, dried and the volume determined by displacement. An indication of the amount of cavity space (i.e. available living space for the cryptofauna) was obtained by wrapping the sample block in light weight, self sealing polythene (Brand names - Saranwrap, Gladwrap) and redetermining the volume. By subtraction, a measure of the cavity space was obtained and expressed as a percentage of cavities occurring in the habitat. This method assumes that all cavities occupied by cryptofauna have some connection with the exterior. The surface area of the sample was determined by coating all surfaces of the block, except the cut surface, with several coats of liquid latex, until a layer of latex was built up. When dry, the latex was peeled off and the surface area measured by a planimeter (HUTCHINGS, in press) (Plate 2e). Finally the block was cut in half with a diamond saw and a visual assessment made of tbe internal structure.

\section{RESULTS}

The cryptofauna of these habitats is diverse and abundant with molluscs, polychaetes, and sipunculans occurring in all samples. 


\section{DISTRIBUTION AND ABUNDANCE OF CRYPTOFAUNA}

All habitats but not every sample contain crustaceans. Other groups such as echinoderms, ascidians, echiurans, and fish (gobies) occur irregularly. Colonial animals are well represented by sponges, ascidians and bryozoans. Molluscs are represented by several abundant species of bivalves and over 90 species of gastropods. More than $50 \%$ of the gastropod species are represented by a single individual and only $10 \%$ are represented by more than five individuals. So that most replicate samples of a habitat do not have gastropod species in common. Polychaetes, certain species of which are very abundant, are represented by over 100 species within the following families: Polynoidae, Chrysopetalidae, Amphinomidae, Phyllodocidae, Syllidae, Nereidae, Glyceridae, Onuphi-dae, Eunicidae, Lumbrineridae, Spioniidae, Magelonidae, Chaetopteridae, Cirratulidae, Opheliidae, Capitellidae, Terebellidae, Sabellidae, and Serpu-lidae. Two of the families, Syllidae and Cirratulidae, often show signs of asexual reproduction either by stolonisation or fragmentation. Sipuncu-lans are extremely abundant and are represented by the following genera, Aspidosiphon, Paraspidosiphon, and Phascolosoma. (Additional genera will probably be found on completion of identification). Cloeosiphon aspergillus, a widely distributed coral reef species, is common and easily recognised by its anterior cap of numerous calcareous plates. Many of the sipunculans are immature. Crustaceans are represented by the following groups, isopods, amphipods, stomatopods, palaemonid shrimps, alpheids, and xanthids. The majids (spider crabs) Tylocarcinus styx, Hyastenus agassizii and Menaethius monoceros are present. Again many of the crustaceans are represented by juveniles.

In all the groups making up the cryptofauna many undescribed species and new records are present so that taxonomic work is progressing slowly and will be dealt with in later publications. For example within one family of polychaetes, the terebellids, eight new species are present, three in undescribed genera. For this reason the results discussed below are based upon the wet weight of the invertebrate groups expressed as a percentage of the total wet weight of the sample of reef rock. The mean weight of invertebrates occurring in the three replicate samples for each habitat has been used. The weight of invertebrates includes crustaceans, echinoderms, molluscs, polychaetes, and sipunculans but does not include colonial ascidians, bryozoans, and sponges, which are often very difficult to completely separate from the coral skeleton. Figures 2 and 3 show the percentage of invertebrates for solid reef habitats with a small surface area (Plate la, b) and for solid reef habitats with a large surface area and easily broken up (Plate 1c, d).

The habitats have been grouped into the three sampling localities, fringing reefs of Lizard Island, and inner and outer Yonge Reef. For these two types of habitats the biomass of invertebrates is significantly 


\section{PAtricia A. Hutchings \& PEnNy D. WEATE}

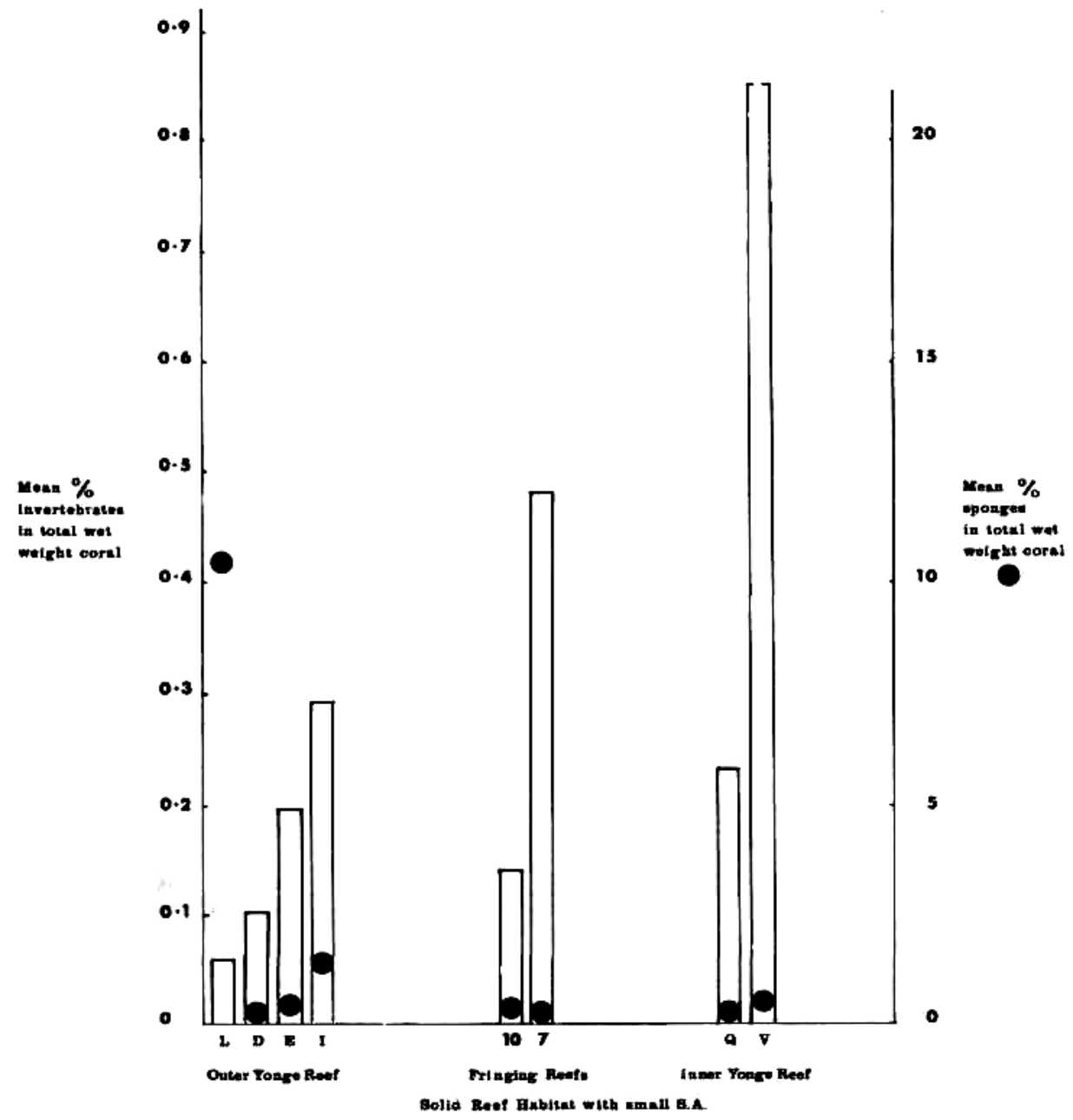

Figure 2. The mean biomass of invertebrates expressed as a percentage of the total wet weight of sample for solid reef habitats with a small surface area. The habitats have been grouped into the 2 sampling areas. 


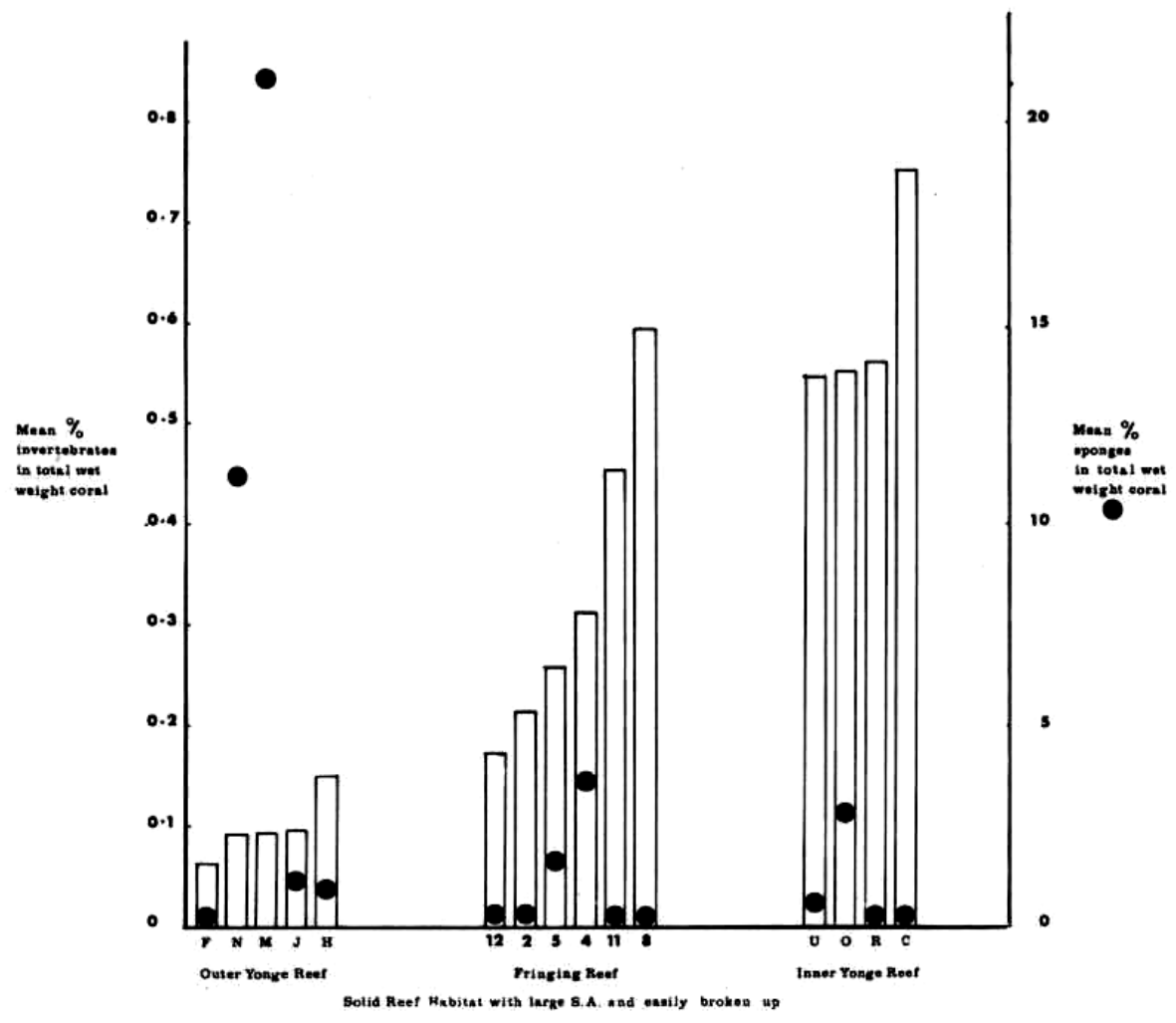

Figure 3. The mean biomass on invertebrates expressed as a percentage of the total wet weight of sample for solid reef habitats witha large surface area and easily broken up. The habitats have been grouped into the 3 sampling areas. The mean \% of sponge occurring in each habitat is also shown. 


\section{Patricia A. Hutchings \& Penny D. WLAte}

greater on inner Yonge than on outer Yonge Reef, with fringing reefs having intermediate values. At this stage all the same type of habitats sampled at one locality are being grouped together even though they were collected at various depths (Habitats on the fringing reefs were collected from depths of 3-20 m, those on inner Yonge from 2-7 $\mathrm{m}$ and those on outer Yonge from 13-35m).

When the invertebrate biomass is broken down into the major component groups of polychaetes, molluscs, crustaceans, and sipunculans, all groups show the same trend of larger biomasses occurring on inner Yonge than on the fringing reefs or outer Yonge. The distribution of the polychaete biomass for habitats with a large surface area and easily broken up, is shown in Figure 4 . The other three types of habitat . dead

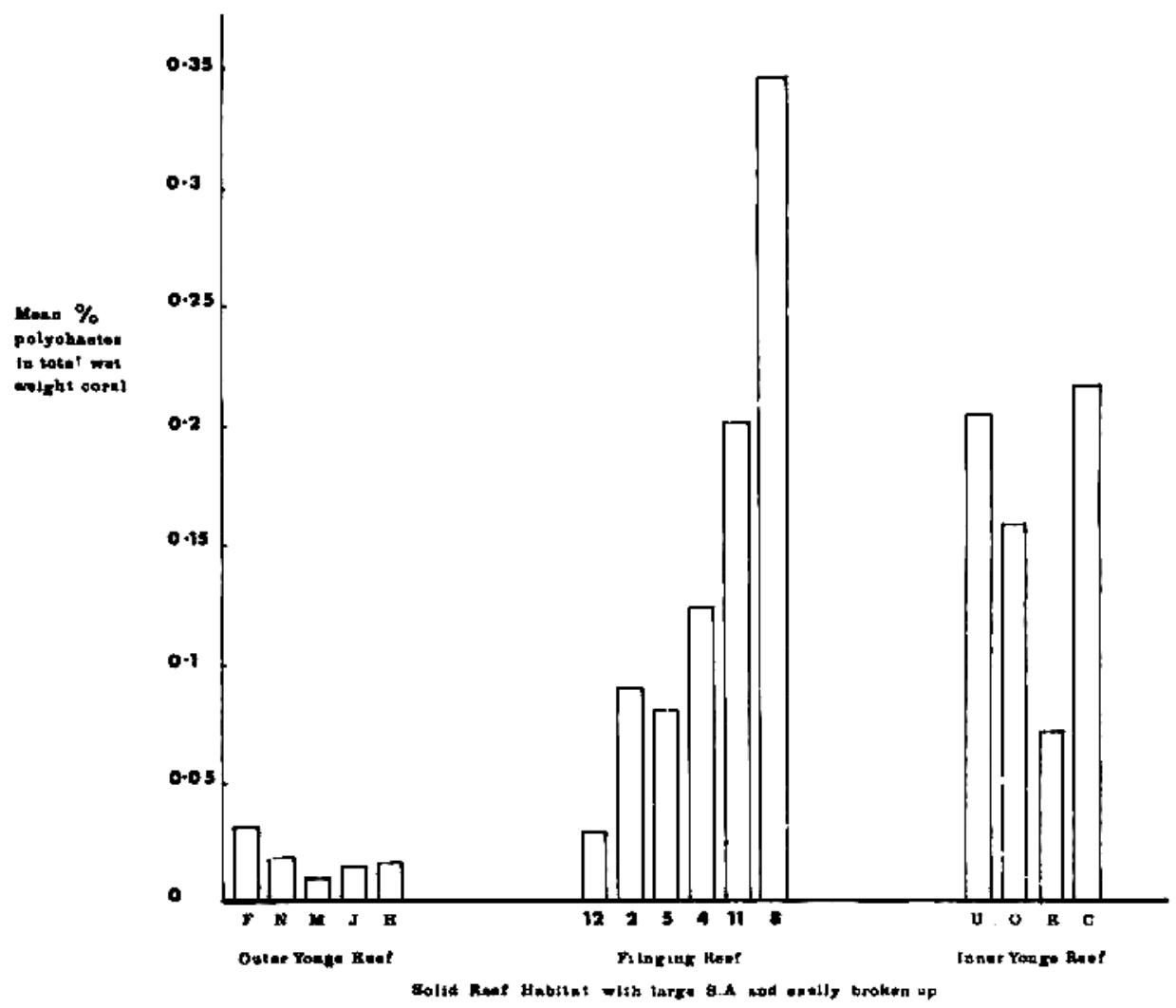

Figure 4. The mean biomass of polychaetes expressed us $J$ percentage of the total wet weight of sample for solid reef habitats with a lame surface area and easily broken up. The habitats have been grouped into the 3 sampling areas. 


\section{DISTRIBUTION AND ABUNDANCE OF CRYPTOFAUNA}

branching coral, those with a high percentage of live coral and thin plates of dead coral, seem to show the same trends, eveh though relatively few samples have been collected.

Although all the major invertebrate groups are more abundant or at least have larger biomasses on inner Yonge than on either outer Yonge or fringing reefs around Lizard, the relative proportions of the invertebrate groups to each other changes. The relative proportions for solid reef habitats with large surface area are given below.

Solid reef habitats, with large SA an easily broken up

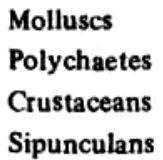

Outer Barrier Inner Yonge Outer Yonge

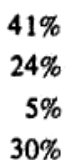

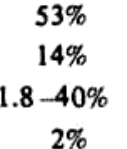

Lizard Island Exposèd Fringing Reefs

$54 \%$
$34 \%$
$6 \%$
$6 \%$

The reasons for these differences are not fully understood. However, environmental factors on outer Yonge must favour settlement and establishment of molluscs in comparison to polychaetes and sipunculans. Whereas inner Yonge conditions are more favourable towards recruitment of polychaetes and sipunculans.

The invertebrate biomass occurring in solid reef habitats with large surface area and easily broken up tends to be higher than in solid reef habitats with small surface area (Figs. 2 \& 3). These two groups of habitats show differences in physical parameters and these are expressed as a series of ratios below. The ranges occurring within the habitats of the two groups are given.

Type of Habitat

Solid reef habitat, large SA easily broken up.* Solid reef habitat, small SA.**

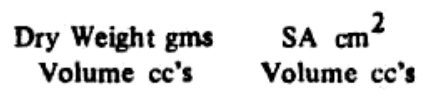

$$
\begin{array}{ll}
1.7-2.0 & 0.9-2.0 \\
2.0-2.1 & 0.6-1.3
\end{array}
$$

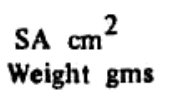

$0.46-0.93$

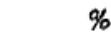

Internal Space
$0.28-0.6$
$3-20 \%$

$10-39 \%$

* Habitat C has been excluded, its ratios are respectively, 1.8, 0.6, 0.3 and $23.8 \%$

** Habitat $\mathrm{V}$ has been excluded its ratios are respectively $2.0,1.3,0.6$ and $3.9 \%$.

Large surface area habitats have a slightly larger volume in relation to weight, than solid reef habitats with a small surface area. They also have a larger surface area in relation to volume or weight than solid reef 


\section{Patricia A. Hutchings \& Penny D. Weate}

habitats with a small surface area. This suggests that surface area, volume in relation to dry weight and internal space are important factors in explaining the larger biomass of invertebrates normally found in solid reef habitats with a large surface area, than in solid reef habitats with a small surface area. Two habitats from inner Yonge, habitat C (large SA) and habitat V (small SA) which both have similar high invertebrate biomasses contradict the above. Their physical parameters fall within the ranges of their respective groups, so that they have been classified correctly, but why such very different habitats physically have similar biomasses of cryptofauna is obscure. The calculation of these ratios was completed after the habitats had been assigned to their groups, suggesting that our initial assessment of habitats into groups underwater is reasonably accurate.

\section{DISCUSSION}

The volume, surface area, density, and internal pore space of a habitat are all inter-related factors in determining the abundance of cyptofauna. There are no direct correlations between biomass of invertebrates and any single physical parameter. This is because different parameters operate at different times for example a large surface area increases the area for larval settlement. If the surface is convoluted the larvae will gain better protection from predation or being washed off the surface by currents or waves during the critical period of habitat penetration. Similar protection will be given by tufted green algae growing on the habitat surface. Once the larvae has penetrated into the habitat, settlement and establishment will depend upon the availability of suitable holes or crevices. These holes must be distributed around the periphery of the habitat with access to the surface to allow the animals to feed etc. Other factors such as the presence of living coral or epifaunal sponges may limit the settlement of invertebrates by feeding on the larvae. PORTER (1974) has shown that corals feed selectively on certain invertebrates, and we have seen corals feeding on epitokous nereids (polychaetes), so corals may also limit successful breeding. Preliminary data indicate that a greater cover of sponges occurs on outer Yonge than in two other sampling areas (Fig. 3) and this may be a factor in explaining the lower invertebrate biomasses found in this area, but more data is needed before this can be substantiated. It may also be necessary to distinguish between boring and epifaunal sponge species. Boring sponges often severely limit the distribution of cryptofauna within a habitat.

We have already shown that the physical parameters of habitats at least within two groups are fairly consistent, indicating other factors must be responsible for the differences in biomass of invertebrates found 


\section{DISTRIBUTION AND ABUNDANCE OF CRYPTOFAUNA}

in similar habitats but in different areas. Probably many factors are involved, we believe the two most important, are the coral species composition in the three areas and the degree of exposure of the three areas. The greatest biomass is found on inner Yonge which is a sheltered area, this is also apparent by the coral species present. Intermediate in exposure are the exposed fringing reefs of Lizard Island. The most exposed area with the smallest biomass is on outer Yonge which receives the full force of the trade winds. Additional samples will be collected from the other three groups of habitats to check that they conform to the same pattern. Current work is testing the importance of exposure. Finally it will be interesting to compare the species composition of the three localities.

\section{ACKNOWLEDGEMENTS}

We should like to thank the Australian Research Grants Committee for finding this study and paying the salary of one of us (PW). We should also like to thank JOHN PICKARD and HARRY RECHER for criticizing the manuscript and HELEN TRANTER for identifying the majids.

\section{REFERENCES}

ARNAUD, P.M. and B.A. THOMASSIN 1976. First records and adaptive significance of boring into a free-living scleractinian coral (Heteropsammia michelini) by a Data Mussel (Lithophaga lessepsiana). Veliger 18 (4) : 367 - 374.

BRANDER, K.M., A.A. MCLEOD and W.F. HUMPHREYS 1971. Comparison of species diversity and ecology of reef-living invertebrates on Aldabra Atoll and at Watamu, Kenya. Symp. Zool. Soc. Lond. 28: 397 - 431.

EBBS, N.K. 1966. The coral-inhabiting polychaetes of the Northern Florida Reef tract. Part I. Aphroditidae, Polynoidae, Amphinomidae, Eunicidae, and Lysaretidae. Bull Mar. Sci. 16 (3) : $485-555$.

GOREAU, T.F., N.I. GOREAU and C.M. YONGE 1972. On the mode of boring in Fungiacava eilatensis (Bivalvia : Mytilidae). J. Zool., Lond. 166: 55 - 60.

GRASSLE, J.F. 1973. Variety in Coral Reef Communities. In: The Biology and Geology of Coral Reefs. Volume II, Biology 1. Academic Press, New York and London : 247 - 270.

HAIGLER, S.A. 1969. Boring mechanisms of Polydora websteri inhabiting Crassostrea virginica. Amer. Zool. 9 : 821 - 888.

HUTCHINGS, P.A. 1974. A Preliminary report on the density and distribution of invertebrates living on coral reefs. Proc. 2nd Internat. Coral Reef Sympos., Great Barrier Reef Commit tee 1 : $285-296$.

HUTCHINGS, P.A. (in press). Quantitative methods for studying the non-colonial cryptofauna of coral reefs. In: Handbook of Coral Reef Research Methods. UNESCO Monographs on Oceanographic Methodology. UNESCO Paris. 


\section{Patricia A. Hutchings \& Penny D. Weate}

KOHN, A.J. and M.C. LLOYD 1973. Polychaetes of truncated reef limestone substrates on eastern Indian Ocean coral reefs: diversity, abundance, and taxonomy. Int. Revue ges. Hydrobiol. 58 (3) : 369 - 399.

Mc CLOSKEY, L.R. 1970. The dynamics of the community associated with a marine scleractinian coral. Int. Revue ges. Hydrobiol. 55 ( 1 ) : $13-81$.

PEYROT-CLAUSADE, M. 1974. Ecological study of coral reef cryptobiotic communities: an analysis of the polychaete cryptofauna. Proc. 2nd Internat. Coral Reef Sympos., Great Barrier Reef Committee 1 : 269 - 283.

PORTER, J.W. 1974. Zooplankton feeding by the Caribbean reef-building coral Montastrea cavernosa. Proc. 2nd Intemat. Coral Reef Sympos., Great Barrier Reef Committee 1 : $111-125$.

REISH, D.J. 1968. The polychaetous annelids of the Marshall Islands. Pacif Set 22 (2) : 208- 231.

RICE, M.E. 1969. Possible boring structures of sipunculids. Amer. Zool. 9 : 803 - 812.

RICHARD, G. 1973. Abondances et dominances des Mollusques dans un ecosysteme corallien (Moorea, Polynesie francaise). Bull. Mus. natn. Nat. Hist. 3 rd ser. 163 : 309 - 313.

RUTZLER, K. 1974. The burrowing sponges of Bermuda. Smithson. Contrib. Zool 165 : 1 32.

RUTZLER, K. and G. RIEGER 1973. Sponge burrowing : Fine structure of Cliona lampa penetrating calcareous substrata. Mar. Biol. 21 : 144 - 162.

SOLIMAN, G.N. 1969. Ecological aspects of some coral-boring gastropods and bivalves of the northwestern Red Sea. Amer. Zool. 9(3) : 887 - 894.

THOMAS, P.A. 1972. Boring sponges of the reefs of Gulf of Mannar and Palk Bay. Proc. 1st Internat. Coral Reef Sympos: 333 - 362.

WILLIAMS, J.A. and S.V. MARGOLIS 1974. Sipunculid burrows in coral reefs: Evidence for chemical and mechanical excavation. Pacif. Sci. 28 (4) : 357 - 359.

ZOTTOLI, R.A. and M.R. CARRIKER 1974. Burrow morphology, tube formation, and microarchitecture of shell dissolution by the spionid polychaete Polydora websteri. Mar. Biol. 27 : 307 - 316. 